\title{
THÉOPHILE GAUTIER, Critique théâtrale, t. XIII septembre 1855-mars 1857
}

\section{Lise Sabourin}

\section{(2) OpenEdition}

\section{Journals}

Édition électronique

URL : https://journals.openedition.org/studifrancesi/45324

DOI : 10.4000/studifrancesi.45324

ISSN : 2427-5856

Éditeur

Rosenberg \& Sellier

\section{Édition imprimée}

Date de publication : 1 août 2021

Pagination : 393

ISSN : 0039-2944

\section{Référence électronique}

Lise Sabourin, « THÉOPHILE GAUTIER, Critique théâtrale, t. XIII septembre 1855-mars 1857 », Studi Francesi [En ligne], 194 (LXV | II) | 2021, mis en ligne le 01 septembre 2021, consulté le 15 octobre 2022. URL : http://journals.openedition.org/studifrancesi/45324; DOI : https://doi.org/10.4000/studifrancesi. 45324

Ce document a été généré automatiquement le 15 octobre 2022

\section{(c)}

Creative Commons - Attribution - Pas d'Utilisation Commerciale - Pas de Modification 4.0 International - CC BY-NC-ND 4.0

https://creativecommons.org/licenses/by-nc-nd/4.0/ 


\title{
THÉOPHILE GAUTIER, Critique théâtrale, t. XIII septembre 1855-mars 1857
}

\author{
Lise Sabourin
}

\section{RÉFÉRENCE}

THÉOPHILE GAUTIER, Critique théâtrale, t. XIII septembre 1855-mars 1857, texte établi, présenté et annoté par P. Berthier, Paris, Honoré Champion, 2020, 785 pp.

1 Depuis son entrée au "Moniteur universel" en avril 1855, Gautier voit son champ de comptes rendus réduit au théâtre, puisque la chronique musicale de ce journal appartient à Fiorentino, alias A. de Rovray, jusqu'à son décès en 1864. C'est une frustration pour ce grand amateur de concerts et d'opéras, mais il la compense en consacrant plus de temps et de place dans sa "Revue dramatique" aux grands théâtres patrimoniaux que sont la Comédie-Française, l'Odéon (où l'on monte Le Cid) et le Théâtre-Italien (avec Médée). Ce qui ne l'empêche pas de fréquenter la Porte-SaintMartin (pour L'Orestie revue par Dumas père ou la reprise de Marino Faliero), le Gymnase (où il analyse La Question d'argent de Dumas fils), le Vaudeville (avec La Fée d'Octave Feuillet), les Folies-Nouvelles (nom du futur théâtre Déjazet où succède à Deburau le mime Paul Legrand), mais aussi les courses de taureaux... et le Cirque, dont il aime toujours l'exotisme, par exemple quand il y contemple les éléphants de Ceylan.

2 George Sand occupe alors les planches, puisque l'Odéon joue Maître Favilla et reprend Claudie, le Gymnase Lucie et Françoise, que le Théâtre-Français monte une adaptation sandienne du Comme il vous plaira shakespearien. Cela permet à Gautier d'y comparer la veine romanesque de Sand, notamment dans Le Château des désertes. Il n'oublie pas de rendre hommage aux amis créateurs qui disparaissent: Heine en février 1856, Théodore Chassériau en octobre.

De septembre 1855 à mars 1857, le Théâtre-Français propose, notamment aux étrangers venus à Paris pour l'Exposition Universelle, toute une série de pièces classiques du répertoire: Tartuffe, Le Misanthrope, Les Femmes savantes, Amphitryon, mais aussi Les 
Fausses Confidences, Le Legs, Turcaret, Le Joueur, Le Mariage de Figaro, Zaïre, Le Cid encore, mais aussi quelques pièces contemporaines: Une Chaîne de Scribe, Pauvres d'esprit de Léon Laya, Guillery d'Edmond About. Tout cela fait réfléchir Gautier sur le jeu qu'il trouve peu naturel des comédiens français, mais aussi sur la structure cornélienne ou la spécificité voltairienne. Il se laisse aussi aller à plus de réflexions sur le théâtre en général, tel qu'il le conçoit idéalement (changement à vue, éclairage plus subtil, illusion des décors). 